\title{
Comparison Analysis of Online Shop between Lazada and Shopee on Students of The Faculty of Economics and Business (FEB) Narotama University Surabaya, Indonesia
}

\author{
Anarki Bayu Sadewo \& R Agus Baktiono
}

Department of Management, Faculty of Economics and Business, Narotama University, Surabaya, Indonesia

\begin{abstract}
This study aims to analyze differences in consumer satisfaction in buying products through the Online Shop between SHOPEE and LAZADA among FEB students of Narotama University Surabaya seen from the perception of how to use applications, promotions, prices and satisfaction. This type of research is comparative research with a quantitative approach. The population in this study were students of the Faculty of Economics and Business at Narotama University who had used both Lazada and Shoppe online shop applications using purposive sampling in the research sample. The research data was obtained by distributing research questionnaires on How to Use, Promotion, Price and Customer Satisfaction, to 85 respondents. The results showed that: (1) There are differences in the variable of how to use the application between the Lazada online shop and Shopee, (2) There is no difference in the variable promotional activities carried out between the Lazada online shop and Shopee, (3) There are differences in the product price variables offered between the Lazada online shop and Shopee, (4 There is no difference in the consumer satisfaction variable in shopping through the Lazada online shop with Shopee.
\end{abstract}

(C) 2020 Author(s). All rights reserved.

Keywords: How to use, Promotion, Price, Customer Satisfaction.

\section{Introduction}

Use the internet to promote their products are known as online businesses or often called online shops The development of technology nowadays has become a very interesting phenomenon in line with the emergence of internet development which is increasingly rapid. With the rapid development of technology making business competition very fierce, so that many small businesses emerge using this internet technology to promote their products so that the products being promoted can be known to all people, especially those who use online shop sites or applications so that people can easily find the product they want. This shows that the internet is very important for progress in this very tough business competition. Businesses.

Online promotion is marketing that is carried out via interactive online computers that connect consumers and sellers electronically (Kotler, 2001). Currently the development of internet technology is growing rapidly. Business people who promote their products online can take advantage of this progress. Broadly speaking, internet marketing is carrying out an act of promoting a product or service that is marketed through the internet media. With the use of online marketing, basically the sellers will be able to introduce and promote their products faster and of course, will be accompanied by fast and on time delivery services to their destination where buyers are located.

Competition in online business is currently getting tougher with the increasing number of business people who take

\footnotetext{
* Corresponding author.

E-mail address: bayusadewo65@gmail.com (Anarki Bayu Sadewo)
} 
advantage of online marketing, where each business person always offers attractive product promotions, the cheapest prices, guaranteed quality of goods if not suitable, good service quality, up to service delivery of goods to consumers. Just look at the competition that occurs between Online Shop Lazada and Shopee. When we look at the promotions carried out by the two online shops, they compete with each other by offering a variety of quality products, promotion of competitive prices, product distribution in accordance with what the seller promises, and others.

Online business, this term we may often hear lately, online business is also an industry with very potential business potential. This happens along with the times, which is currently the trend with online shopping that is being implemented by people all over the world, including Indonesia. From this, many companies initially implemented offline businesses and then began to expand into online businesses in droves.

Based on the E-Commerce Map released by iprice.co.id, Shopee has managed to maintain its first position as top ecommerce for ten consecutive quarters based on the ranking on the PlayStore. In the second quarter of 2019, Shopee also led the AppStore ranking category. However, based on the average number of site visitors on a monthly basis, Shopee was beaten by Tokopedia. Monthly visitors to the Tokopedia site reached 140.4 million visitors while Shopee had 90.7 million visitors. Meanwhile, Lazada and Tokopedia compete fiercely for second place based on the ranking on the PlayStore. However, in the last two quarters of 2019, Tokopedia managed to overtake Lazada in second place. Bukalapak tends to stagnate in fourth position, even though in the third quarter of 2018 for the first time Bukalapak succeeded in replacing Tokopedia's position in third place. Sale Stock Indonesia, which changed its name to Sorabel, became a newcomer in the second quarter of 2018 which was ranked eighth. A year later, Sorabel managed to climb to fifth place in the second quarter of 2019. As for newcomers this quarter, Alfacart managed to occupy the top $10 \mathrm{e}-$ commerce based on the PlayStore ranking.

For most consumers, they will buy products through the Online Shop, when the sellers can provide satisfaction to consumers. Satisfaction is meant here, is satisfaction with the quality of the product purchased in accordance with what is offered, the prices they offer are quite competitive with prices offered by other sellers, distribution and delivery of products on time, always offering product promotions, the quality of service provided by the seller during consumers are in touch with sellers and there is a guarantee that the goods will be returned if they do not match what was ordered. These are the things that will generally make consumers feel satisfied in buying products through the OnlineShop.

Delivery time is the main spearhead in online marketing, and sellers like it or not and like it or not will make this a strategy in their marketing. Apart from delivery time, service quality is also the main weapon for sellers who are marketing online. Service quality is an effort to meet the needs of what consumers want and the accuracy of delivery according to consumer expectations or customers (Tjiptono, 2007). Thus the quality of service is very important for entrepreneurs if the quality of service is appropriate, then what consumers want indirectly consumers will buy their products. With the good quality service provided by sellers to buyers, this will certainly further increase customer loyalty in the future. future. Loyal customers, will always buy products from sellers that they have been familiar with and who always provide good quality service to the eyes of customers. Customer loyalty is a deeply held commitment to buy or support back preferred products or services for the future despite the influence situations and marketing efforts have the potential to cause customers to switch. (Kotler and Keller, 2009).

\section{Literature Review}

\subsection{How to use}

E-commerce is an act of conducting business transactions electronically using the internet as the main communication medium. E-commerce is related to selling, advertising, ordering products which are all done via the internet. Electronic Business, is the scope of electronic trading activities in a broad sense. E-commerce applications are structured based on technology infrastructure, namely a combination of computers, communication networks and communication software. Thus, it can be said that the application of E-Commerce is closely related to the use of information technology. One of the important elements in implementing an information system is acceptance of the system. Acceptance of information systems can be measured by several evaluation models, including evaluation models that are often used to measure acceptance of information systems (Wilkinson, 2000), namely: End User 
Computing Satisfaction, Task Technology Fit, Human Organization-Technology (HOT), and Technology Acceptance Model (TAM) (Puspita, 2020; Scherer, Siddiq, \& Tondeur, 2019; Rosalina, 2017). Davis et.al. (1989) developed TAM to examine the determinants of users' use of information systems. In subsequent studies, this TAM then developed not only related to perceived usefulness and perceived ease of use, but then increased with the dimensions of Attitude Toward Using and actual use (Davis, 1989).

\subsection{Promosi Online}

Online promotion is marketing that can be done through an interactive online computer system that can connect consumers with sellers electronically. Commercial online services are services that offer information services with online marketing that pay monthly dues. (Kotler, 2001). According to Berman (2016) \& Gunawan, Andrianto, \& Schoonderbeek (2017), online marketing is a promotional strategy developed based on the times and sophistication of human technology that can be used to promote products or services through the internet network.

\subsection{Price}

Price is the only element of the marketing mix that generates sales revenue because the other element is incurring costs. The price according to Pangemanan, Ropa, \& Walukow (2020) is the amount of value that consumers exchange for the benefit of owning or using a product or service whose value is determined by the buyer and seller through bargaining, or set by the seller for the same price against all buyers. According to Tjiptono (2014) states that price has an important role both at the macro (for the economy in general) and micro (for consumers and companies). Thus, product price is the main determinant of market demand for the product concerned. In addition, price affects the company's competitive position and market share.

\subsection{Customer Satisfaction}

Customer satisfaction is the level of someone's feelings after comparing the performance or the results felt with expectations. So the level of satisfaction is a function of the difference between perceived performance and expectations. What if the performance is below expectations, then consumers will be disappointed. If performance is in accordance with expectations, then consumers will be satisfied with consumer expectations can be shaped by past experiences, comments from relatives and promises of marketing information and rivals. According to Kotler (2001): satisfaction is a feeling of pleasure or disappointment obtained after comparing between results obtained with the desired hope. Furthermore, according to Utama (2017) satisfaction is an emotional state, their post-purchase reaction can be in the form of anger, dissatisfaction, annoyance, neutrality, joy, or pleasure. Often times the feeling of fasting or not fasting with a purchased product, actually the feeling arises when comparing what is expected with what is recommended.

\subsection{Hipotesis Penelitian}

The hypothesis that the authors propose in this study is: "There are differences in consumer satisfaction in buying products through Online Shope between SHOPEE and LAZADA among students of FEB, Narotama University, Surabaya".

\section{Methods}

The approach used in this research is a quantitative approach and comparative research types. The quantitative approach is a scientific approach designed to answer research questions using statistical numbers and the research method uses the Difference Test method. The population in this study were students of the Faculty of Economics and Business at Narotama University who had used both Lazada and Shoppe online shop applications as many as 567 students who were active in the current academic year 2019/2020. The sampling technique used by the author is non probability sampling. According to Sugiyono (2010) non probability sampling is a sampling technique that provides 
equal opportunities / opportunities for each element or member of the population to be selected as a sample. In this study, respondents who filled out the questionnaire were respondents who had made purchases at Lazada and shopee. Because the population is known, to determine the number of samples in this study will use the Slovin formula. By using the Slovin formula, there were as many as 85 students in the sample.

This study uses 4 observation variables to be studied. Where the use variable consists of 4 indicators adopted from Davis (1993), the promotion variable consists of 4 indicators adopted from Kotler \& Keller (2009), the price variable consists of 4 indicators adopted from Kotler \& Armstrong (2012). , and the consumer satisfaction variable consists of 6 indicators adopted from Kotler \& Keller (2009).

Sources of data in this study are primary data and secondary data. Primary data was obtained by distributing questionnaires to FEB students of Narotama University Surabaya who used online shop Lazada and Shopee applications and secondary data was obtained based on publication data and previous research journals.

In this study, the Paired Sample T Test is a test used to compare the difference between the two means of the two pairs of samples with the assumption that the data is normally distributed. Paired samples come from the same subject, each variable is taken when the situations and circumstances are different. Paired t-test is a test conducted to prove whether there is a significant difference between the 2 samples, in this study it is consumer satisfaction. Shopee and Lazada application users.

\section{Result and Discussions}

\subsection{Descriptive Statistics}

Table 1 Descriptive of Respondents Based on Gender

\begin{tabular}{llrrrr}
\hline \multicolumn{5}{c}{ Gender } & \\
\hline & & & \multicolumn{2}{c}{ Cumulative } \\
Valid & Frequency & Percent & Valid Percent & \multicolumn{1}{c}{ Percent } \\
& Male & 32 & 37,6 & 37,6 & 37,6 \\
& Women & 53 & 62,4 & 62,4 & 100,0 \\
& Total & 85 & 100,0 & 100,0 & \\
\hline
\end{tabular}

Source: Questionnaire, data processed by researchers, 2020

Based on table 1 it can be seen that male respondents were 32 people (37.6\%) while female respondents were 53 people $(62.4 \%)$. Thus, in this study the majority of respondents were women.

Tabel 2 Descriptive Respondents Based on Purchase Frequency

\begin{tabular}{llrrrr}
\hline \multicolumn{5}{c}{ Purchase Frequency } \\
\hline & & & & Cumulative \\
Valid & Once Once & 20 & 23,5 & 23,5 & 23,5 \\
& More Than 2 Times & 34 & 40,0 & 40,0 & 63,5 \\
& Often Enought & 20 & 23,5 & 23,5 & 87,1 \\
Very Often & 11 & 12,9 & 12,9 & 100,0 \\
& Total & 85 & 100,0 & 100,0 & \\
\hline
\end{tabular}

Source: Questionnaire, data processed by researchers, 2020

Based on table 2, it can be seen that as many as 34 people (40.0\%) of respondents bought goods through an online shop more than 2 times, as many as 20 people $23.5 \%$ each) respondents bought goods through an online shop quite often and once, while the remaining 11 people $(12.9 \%)$ of respondents buy goods through an online shop very often. So it can be concluded that the majority of respondents bought goods through an online shop more than 2 times. 


\subsection{Data Analysis and Hypothesis Testing}

\subsubsection{Validity test}

Test the validity and reliability of each variable obtained from the results of data processing with the SPSS program can be seen in the following illustration table 3 .

Table 3 Validity and Reliability Test Results

\begin{tabular}{|c|c|c|c|c|}
\hline \multicolumn{5}{|c|}{ Item-Total Statistics } \\
\hline & $\begin{array}{l}\text { Scale Mean if } \\
\text { Item Deleted }\end{array}$ & $\begin{array}{l}\text { Scale Variance if } \\
\text { Item Deleted }\end{array}$ & $\begin{array}{l}\text { Corrected Item- } \\
\text { Total Correlation }\end{array}$ & $\begin{array}{l}\text { Cronbach's Alpha if } \\
\text { Item Deleted }\end{array}$ \\
\hline $\mathrm{x} 111$ & 139.5647 & 135.892 & 0.240 & 0.896 \\
\hline $\mathrm{x} 112$ & 140.1412 & 133.242 & 0.333 & 0.895 \\
\hline $\mathrm{x} 113$ & 140.0118 & 134.464 & 0.265 & 0.896 \\
\hline x114 & 139.3294 & 135.224 & 0.294 & 0.896 \\
\hline $\mathrm{x} 211$ & 139.5529 & 132.703 & 0.471 & 0.894 \\
\hline $\mathrm{x} 212$ & 140.1529 & 127.155 & 0.526 & 0.892 \\
\hline $\mathrm{x} 213$ & 140.2941 & 129.115 & 0.488 & 0.893 \\
\hline $\mathrm{x} 214$ & 139.8235 & 133.647 & 0.349 & 0.895 \\
\hline x311 & 138.9647 & 137.296 & 0.234 & 0.896 \\
\hline $\mathrm{x} 312$ & 139.3529 & 135.255 & 0.262 & 0.896 \\
\hline $\mathrm{x} 313$ & 139.9176 & 132.076 & 0.432 & 0.894 \\
\hline $\mathrm{x} 314$ & 139.2588 & 135.813 & 0.236 & 0.896 \\
\hline x411 & 140.0353 & 134.273 & 0.327 & 0.895 \\
\hline x412 & 140.1176 & 125.867 & 0.619 & 0.890 \\
\hline x413 & 140.2588 & 127.242 & 0.596 & 0.891 \\
\hline $\mathrm{x} 414$ & 140.0235 & 134.214 & 0.279 & 0.896 \\
\hline x415 & 139.9882 & 131.726 & 0.399 & 0.894 \\
\hline x416 & 139.4824 & 135.467 & 0.277 & 0.896 \\
\hline $\mathrm{x} 1 \mathrm{~s} 1$ & 139.7647 & 133.658 & 0.224 & 0.898 \\
\hline $\mathrm{x} 1 \mathrm{~s} 2$ & 140.1529 & 124.607 & 0.689 & 0.889 \\
\hline x1s3 & 140.2706 & 127.176 & 0.624 & 0.890 \\
\hline $\mathrm{x} 1 \mathrm{~s} 4$ & 139.7412 & 131.789 & 0.472 & 0.893 \\
\hline $\mathrm{x} 2 \mathrm{~s} 1$ & 140.0353 & 135.415 & 0.229 & 0.897 \\
\hline$x 2 s 2$ & 140.1176 & 126.319 & 0.595 & 0.891 \\
\hline$x 2 s 3$ & 140.2471 & 127.783 & 0.605 & 0.891 \\
\hline $\mathrm{x} 2 \mathrm{~s} 4$ & 140.0235 & 132.714 & 0.347 & 0.895 \\
\hline $\mathrm{x} 3 \mathrm{~s} 1$ & 139.5176 & 134.134 & 0.297 & 0.896 \\
\hline $\mathrm{x} 3 \mathrm{~s} 2$ & 140.1294 & 126.876 & 0.545 & 0.892 \\
\hline $\mathrm{x} 3 \mathrm{~s} 3$ & 140.2706 & 129.200 & 0.466 & 0.893 \\
\hline $\mathrm{x} 3 \mathrm{~s} 4$ & 139.5647 & 133.820 & 0.338 & 0.895 \\
\hline $\mathrm{x} 4 \mathrm{~s} 1$ & 139.6824 & 135.981 & 0.224 & 0.897 \\
\hline$x 4 s 2$ & 140.1882 & 124.297 & 0.627 & 0.890 \\
\hline $\mathrm{x} 4 \mathrm{~s} 3$ & 140.3059 & 126.048 & 0.623 & 0.890 \\
\hline $\mathrm{x} 4 \mathrm{~s} 4$ & 140.0353 & 133.987 & 0.281 & 0.896 \\
\hline$\times 4 s 5$ & 139.9882 & 131.726 & 0.399 & 0.894 \\
\hline$\times 4 s 6$ & 139.5765 & 133.890 & 0.421 & 0.894 \\
\hline
\end{tabular}

Source: Questionnaire, data processed by researchers, 2020

Based on the illustration of table 3, all statement items in the questionnaire are declared valid, because the value of all statement items $>r_{\text {table. }}$. The amount of rtabel based on the statistical table is 0.2133. Meanwhile, the Cronbach's Alpha value for each statement item in the questionnaire $>0.6$, so that all statement items in the questionnaire can be declared reliable. Thus it can be said that all statement items in the questionnaire have met the valid and reliable 
elements.

\subsubsection{Hypothesis test}

The statistical difference test is carried out to test statistically the difference, whether it is significant or not, on the average difference in the variables of How to Use Applications, Product Promotion, Product Prices, and Consumer Satisfaction. The statistical difference test in this study was carried out using paired sample t-test.

Hypothesis testing with two different means for pairwise observations is carried out if the two samples are used to test the null hypothesis that $\mu 1=\mu 2$, indicates the results of paired observations.

\section{(1) Hypothesis Testing Differences in Mean Variables How to Use Applications}

The analysis steps are carried out using the paired sample t-test variable. How to use the application is as follows:

(a) Hypothesis formulation: $\mathrm{H} 0$ and $\mathrm{H} 1$

H0: $\mu 1=\mu 2$ or $(\mu 1-\mu 2)=0$, meaning that there is no difference in how to use the application

$\mathrm{H} 1: \mu 1 \neq \mu 2$ or $(\mu 1-\mu 2) \neq 0$, meaning that there are differences in how to use the application

(b) Determine the level of significance $(\alpha)$

The value of $\mathrm{t}$ table $=\mathrm{t}(0.05 ; 85-4)=1.989$

(c) The decision criteria are as follows:

H0 is accepted if: $-1,989<\mathrm{t}<1,989$

H0 is rejected if: $\mathrm{t}>1,989$ or $\mathrm{t}<-1,989$

(d) The calculation of the t value is carried out using the SPSS program, the tcount is obtained in table 4 .

Table 4 Value of $t_{\text {count }}$ How to Use Applications

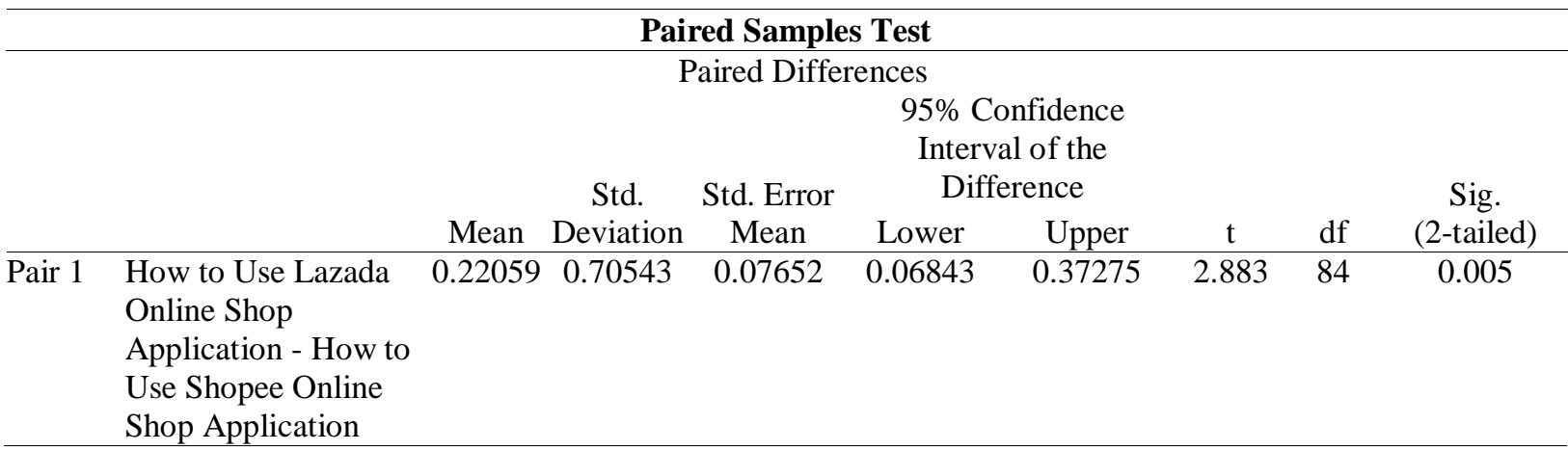

Source: Questionnaire, data processed by researchers, 2020

Based on the calculation results, the calculated value of how to use the application is 2.883 , because $t=2.883>1.989$, $\mathrm{H} 0$ is rejected and $\mathrm{H} 1$ is accepted. This means that there are empirical differences in the variables of how to use the application between Lazada's online shop and Shopee.

\section{(2) Hypothesis Testing for Difference in Promotion Variables}

The analysis steps are carried out using the paired sample t-test, the promotional variables are as follows:

(a) Hypothesis formulation: $\mathrm{H} 0$ and $\mathrm{H} 1$

H0: $\mu 1=\mu 2$ or $(\mu 1-\mu 2)=0$, meaning that there is no difference in promotional activities

$\mathrm{H} 1: \mu 1 \neq \mu 2$ or $(\mu 1-\mu 2) \neq 0$, meaning that there are differences in promotional activities 
(b) Determine the level of significance $(\alpha)$

The value of $\mathrm{t}$ table $=\mathrm{t}(0.05 ; 85-4)=1.989$

(c) The decision criteria are as follows:

H0 is accepted if: $-1,989<\mathrm{t}<1,989$

$\mathrm{H} 0$ is rejected if: $\mathrm{t}>1,989$ or $\mathrm{t}<-1,989$

(d) The calculation of the $t$ value is carried out using the SPSS program, the tcount is obtained in table 5 .

Table 5 The calculated value of promotional activities

\begin{tabular}{|c|c|c|c|c|c|c|c|c|c|}
\hline \multicolumn{10}{|c|}{ Paired Samples Test } \\
\hline \multicolumn{10}{|c|}{ Paired Differences } \\
\hline & & \multirow[t]{2}{*}{ Mean } & \multirow[t]{2}{*}{$\begin{array}{c}\text { Std. } \\
\text { Deviation }\end{array}$} & \multirow[t]{2}{*}{$\begin{array}{l}\text { Std. Error } \\
\text { Mean }\end{array}$} & \multicolumn{2}{|c|}{$\begin{array}{l}\text { 95\% Confidence } \\
\text { Interval of the } \\
\text { Difference }\end{array}$} & \multirow[t]{2}{*}{$\mathrm{t}$} & \multirow[t]{2}{*}{ df } & \multirow[t]{2}{*}{$\begin{array}{l}\text { Sig. (2- } \\
\text { tailed) }\end{array}$} \\
\hline & & & & & Lower & Upper & & & \\
\hline Pair 1 & $\begin{array}{l}\text { Lazada promotions } \\
\text { Shopee promotions }\end{array}$ & $\begin{array}{c}0,=.150 \\
00\end{array}$ & 0.70942 & 0.07695 & -0.00302 & 0.30302 & 1.949 & 84 & 0.055 \\
\hline
\end{tabular}

Source: Questionnaire, data processed by researchers, 2020

Based on the calculated results, the value of promotional activities is 1.949 , because $t=1.949<1.989, \mathrm{H} 0$ is accepted and $\mathrm{H} 1$ is rejected. This means that there is no empirical difference in the promotional activities between online shop Lazada and Shopee.

\section{(3) Hypothesis Testing of Average Differences in Price Variables}

The analysis steps are carried out using the paired sample t-test, the price variable is as follows:

(a) Hypothesis formulation: $\mathrm{H} 0$ and $\mathrm{H} 1$

H0: $\mu 1=\mu 2$ or $(\mu 1-\mu 2)=0$, meaning that there is no difference in price

$\mathrm{H} 1: \mu 1 \neq \mu 2$ or $(\mu 1-\mu 2) \neq 0$, meaning there is a price difference

(b) Determine the level of significance $(\alpha)$

The value of $\mathrm{t}$ table $=\mathrm{t}(0.05 ; 85-4)=1.989$

(c) The decision criteria are as follows:

H0 is accepted if: $-1,989<\mathrm{t}<1,989$

H0 is rejected if: $\mathrm{t}>1,989$ or $\mathrm{t}<-1,989$

(d) The calculation of the t value is carried out using the SPSS program, the tcount is obtained as follows:

Table 6 The $\mathrm{t}_{\text {count }}$ of the Price Variable

Paired Samples Test

Paired Differences

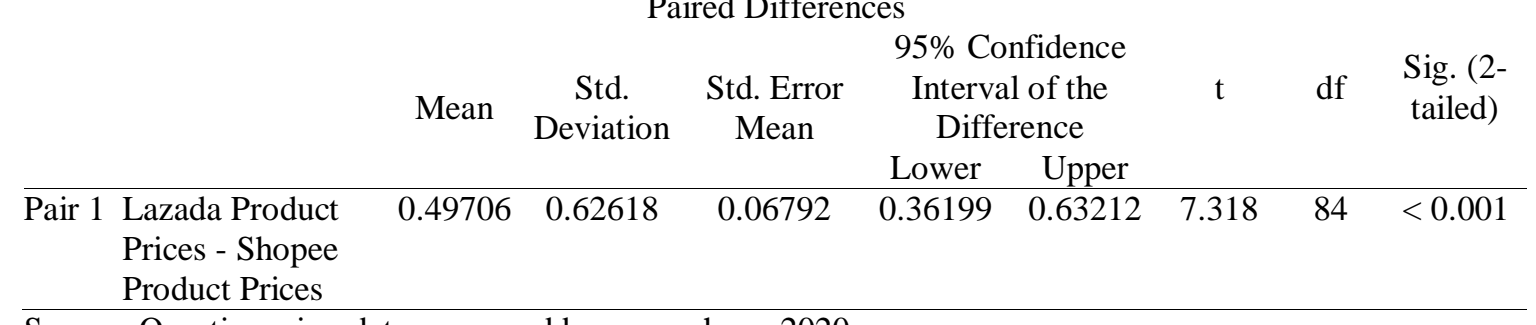

Source: Questionnaire, data processed by researchers, 2020

Based on the calculation results know the value of the price variable is 7.318 , because $t=7,318>1,989, \mathrm{H} 0$ is rejected 
and $\mathrm{H} 1$ is accepted. This means that there are empirical differences in the product price variables offered between Lazada's online shop and Shopee's.

\section{(4) Hypothesis Testing for Difference in Average Consumer Satisfaction Variables}

The analysis steps are carried out using paired sample t-test, the variable customer satisfaction is as follows:

(a) Hypothesis formulation: $\mathrm{H} 0$ and $\mathrm{H} 1$

H0: $\mu 1=\mu 2$ or $(\mu 1-\mu 2)=0$, meaning that there is no difference in customer satisfaction

$\mathrm{H} 1: \mu 1 \neq \mu 2$ or $(\mu 1-\mu 2) \neq 0$, meaning that there is a difference in satisfaction

(b) Determine the level of significance $(\alpha)$

The value of $\mathrm{t}$ table $=\mathrm{t}(0.05 ; 85-4)=1.989$

(c) The decision criteria are as follows:

H0 is accepted if: $-1,989<\mathrm{t}<1,989$

H0 is rejected if: $\mathrm{t}>1,989$ or $\mathrm{t}<-1,989$

(d) The calculation of the t value is carried out using the SPSS program, the tcount is obtained as follows:

Table 7 Value of $\mathrm{t}_{\text {count }}$ of Consumer Satisfaction Variable

\begin{tabular}{|c|c|c|c|c|c|c|c|c|}
\hline \multicolumn{9}{|c|}{ Paired Samples Test } \\
\hline \multicolumn{9}{|c|}{ Paired Differences } \\
\hline & \multirow[t]{2}{*}{ Mean } & \multirow[t]{2}{*}{$\begin{array}{c}\text { Std. } \\
\text { Deviation }\end{array}$} & \multirow[t]{2}{*}{$\begin{array}{l}\text { Std. Error } \\
\text { Mean }\end{array}$} & \multicolumn{2}{|c|}{$\begin{array}{l}95 \% \text { Confidence } \\
\text { Interval of the } \\
\text { Difference }\end{array}$} & \multirow[t]{2}{*}{$\mathrm{t}$} & \multirow[t]{2}{*}{$\mathrm{df}$} & \multirow[t]{2}{*}{$\begin{array}{l}\text { Sig. (2- } \\
\text { tailed) }\end{array}$} \\
\hline & & & & Lower & Upper & & & \\
\hline $\begin{array}{ll}\text { Pair } 1 \text { Lazada Customer } \\
\text { Satisfaction - } \\
\text { Shopee Customer } \\
\text { Satisfaction }\end{array}$ & -0.02235 & 0.19709 & 0.02138 & -0.06486 & 0.02016 & -1.046 & 84 & 0.299 \\
\hline
\end{tabular}

Source: Questionnaire, data processed by researchers, 2020

Based on the calculation results, the calculated value of how to use the application is-1.046, because $t=-1.046$ $<1.989$, H0 is accepted and H1 is rejected. This means that there is no empirical difference in the variable of consumer satisfaction in shopping through the Lazada online shop with Shopee.

\subsection{Analysis and Discussion of Research Results}

Based on the analysis of different tests that have been carried out, it can be concluded that the hypothesis that the author puts forward, which reads "There are differences in consumer satisfaction in buying products through Online Shope between Lazada and Shopee among FEB students of Narotama University Surabaya", is less proven empirically. This is because of the four variables used to perform the difference test analysis, which among others consist of: variables how to use applications, promotions, prices, and customer satisfaction, it turns out that the promotional activity variable and the consumer satisfaction variable show no difference, while the two Another variable, namely the variable how to use the application and the variable price of the product, the result states that there is a significant difference between the online shop Lazada and Shopee.

Based on data testing using different test paired samples test as the author explains above, the conclusion is that there are differences in how to use the online shop application, and product price offers between Lazada and Shopee anline shop among FEB students of Narotama University Surabaya. There are differences in how to use the online shop application between Lazada and Shopee, in practice in the field and most of those faced by users, basically according to the author's opinion because: 
(1) The Lazada online shop application is simpler and easier to use compared to the Shopee online shop application, where the features of the Lazada online shop are very easy for consumers to understand when ordering goods when transacting online than the features in Shopee. Thus, consumers in general will see that the Lazada online shop application is more familiar to be used by all groups and groups of people who wish to transact and shop for products electronically through the online shop rather than the Shopee online shop application.

(2) Meanwhile, from the results of the paired sample t test, the variable promotional activities and customer satisfaction between Lazada's online shop and Shopee were stated to have no differences. Based on the author's observations in the field and interviews with several users and online shop buyers, both Lazada and Shopee and others, there is no difference in promotional activities and customer satisfaction due to several reasons:

(a) Both the online shop Lazada and Shopee carry out intense promotional activities on every media used, whether in Youtube, television, or other media.

(b) The goods offered at the Lazada and Shopee online shops are generally the same, both in terms of quality, price, delivery time, guaranteed return of goods and so on, so that when viewed from the buyer's comments after making online transactions and receiving goods, said the same, although sometimes there are pluses and minuses, especially when the goods received by the buyer do not match the goods promised, the goods sent are bad goods and cannot be used.

\section{Conclusions}

Based on the data analysis and discussion, it can be concluded that:

1. There is an empirical difference in the variable of how to use the application between Lazada's online shop and Shopee, where $\mathrm{t}_{\text {count }}>\mathrm{t}_{\text {table }}$, namely $2.883>1.989$.

2. There is no empirical difference in the variable promotional activities carried out between Lazada's online shop and Shopee, where $t_{\text {count }}>t_{\text {table }}$, namely $1.949<1.989$.

3. There is an empirical difference in the product price variables offered between Lazada's online shop and Shopee's, where $t_{\text {count }}>t_{\text {table }}$, namely $7.318>1.989$.

4. There is no empirical difference in the consumer satisfaction variable in shopping through Lazada's online shop with Shopee, where $t_{\text {count }}>t_{\text {table }}$, which is $-1.046<1.989$.

\section{References}

Berman, B. (2016). Planning and implementing effective mobile marketing programs. Business Horizons, 59(4), 431439.

Davis, F.D. 1989. Perceived usefulness, Perceived Ease of Use, and User Acceptance of Information Technology. MIS Quartely.

Gunawan, D. N., Andrianto, N., \& Schoonderbeek, W. (2017). Enhancing Business Performance Of CV. Berkat Anugerah Malang Using Online Marketing Strategies. International Journal of Applied Business and International Management, 2(1), 82-104.

Kotler, P. (2001). Manajemen Pemasaran : Analisis, Perencanaan, Implementasi, dan Kontrol. Jakarta: Prehallindo.

Kotler, P., \& Armstrong, G. (2012). Principles of Marketing, 14th ed. New Jersey: Pearson Prentice Hall

Kotler, P., \& Keller, K.L. (2009). Manajemen Pemasaran. Jakarta: Erlangga.

Pangemanan, S. A., Ropa, G., \& Walukow, I. M. (2020, August). Impact of Products, Prices and Locations on Consumer Purchasing Decisions in Manado's Boulevart Resto and Café Service Entities. In First International Conference on Applied Science and Technology (iCAST 2018) (pp. 78-82). Atlantis Press.

Puspita, S. C. (2020). Analysis of Hospital Information System Implementation Using the Human-OrganizationTechnology (HOT) Fit Method: A Case Study Hospital in Indonesia. European Journal of Business and Management Research, 5(6).

Rosalina, R., Utami, M. C., Kumaladewi, N., \& Putra, S. J. (2017, August). The psychometric and interpretative analyses for assessing the end-user computing satisfaction questionnaire. In 2017 th International Conference on Cyber and IT Service Management (CITSM) (pp. 1-6). IEEE. 
Scherer, R., Siddiq, F., \& Tondeur, J. (2019). The technology acceptance model (TAM): A meta-analytic structural equation modeling approach to explaining teachers' adoption of digital technology in education. Computers \& Education, 128, 13-35.

Sugiyono., 2010, Metode Penelitian Pendidikan Pendekatan Kuantitatif, Kualitatif dan R \&D, Alfabeta, Bandung Tjiptono, F. (2007). Strategi Pemasaran. Yogyakarta: Andi Ofset.

Utama, I. P. (2017). The Mediating Role of Relationship Quality in Association of Brand Performance and Repurchase Intention: Evidences of Balinese Traditional Food Business at Star Hotels. WCBM 2017, 179.

Wilkinson, J. W. \& Cerullo, M. J. (2000). Accounting Information System, Essential Concept and Application. USA: John Wiley \& Sons, Inc. 